\title{
Impact Assessment of Polluted Stream on Groundwater: Case Study of Polluted Gege Stream, Ibadan, Nigeria
}

\author{
Oluseyi E. Ewemoje ${ }^{1}$, Temitayo A. Ewemoje ${ }^{1} \&$ Sunday D. Ajayi ${ }^{1}$ \\ ${ }^{1}$ Department of Agricultural and Environmental Engineering, University of Ibadan, Ibadan, Nigeria \\ Correspondence: Oluseyi E. Ewemoje, Department of Agricultural and Environmental Engineering, University of \\ Ibadan, Ibadan, Nigeria. Tel: 234-805-560-5370. E-mail: seyiajayi2@yahoo.com
}

Received: March 1, 2015 Accepted: March 30, 2015 Online Published: May 26, 2015

doi:10.5539/enrr.v5n2p189

URL: http://dx.doi.org/10.5539/enrr.v5n2p189

\begin{abstract}
Contamination of groundwater may be as a result of human activities especially in urban cities where there is usually high population density. Release of domestic wastes and small scale agro-processing wastes into the environment has tendency to pollute the surface water which may ultimately leads to groundwater pollution. The study evaluated Physico-chemical and microbial characteristics of wells located along Gege stream from 4 tube wells (w1, w2, w3, and w4,) located at both sides of Gege stream at a radius of influence of $20 \mathrm{~m}(\mathrm{w} 1), 30 \mathrm{~m}$ (w2), $39 \mathrm{~m}$ (w3), and $20 \mathrm{~m}$ (w4), respectively. The samples were collected every forthnightly for 5 months early in the morning (7-8 am) when the waste water load on the receiving surface water is at its peak. Physico-chemical and microbial characteristics of the groundwater observed were; $\mathrm{pH}, 7.0-7.9$, Temperature $10-29{ }^{\circ} \mathrm{C}$, Dissolved Oxygen 3.5-5.5 mg/L, Total solids 1375-2865 mg/L, Total dissolved solids 1.2-3.5 mg/L, BOD $4.3-9.6 \mathrm{mg} / \mathrm{L}$, COD 7.0-18.3 mg/L, Electrical Conductivity $980-8075 \mathrm{mg} / \mathrm{L}, \mathrm{Pb}^{++} 0.0-0.1 \mathrm{mg} / \mathrm{L}, \mathrm{Cu}^{++} 0.01-0.4 \mathrm{mg} / \mathrm{L}, \mathrm{Mg}^{++}$ 0.5-2.7 mg/L, Al, 0.5-3.4 mg/L Fe ${ }^{++} 0.2-0.6 \mathrm{mg} / \mathrm{L}, \mathrm{NO}_{3} 1.2-3.5 \mathrm{mg} / \mathrm{L}, \mathrm{CL} 15.0-18.3 \mathrm{mg} / \mathrm{L}$ and high microbial load was observed. All water samples collected from the well showed the presence of fecal contaminants which was higher than WHO water standard, the prevalent bacteria present in the sample include Enterobacter, Proteus sp;Pseudomonas, and Aeromonas. The values of Physciochemical parameters and Metal content values were higher in all the parameters except in TDS, Mg, $\mathrm{P}^{\mathrm{H}}$ and Temprature which were within recommended range. Nitrate in the samples collected from the wells are not to high compare to WHO water standard but its presence may be harmful especially to infants causing disease called cyanosis or blue baby syndrome in infant if consumed. The result showed that water samples from the Gege stream is highly polluted, contained toxic substances and high microbial load, which has great effect on the surrounding wells due to high strength of the waste water infiltrating into the wells. Improved monitoring of effluents from Abattoirs, and wastewater discharged into the stream is needed by the agencies saddled with the responsiblity of Public health, There is need to educate the residence of the environment where this study was carried out, that well water closer to Gege stream is not suitable for domestic use at home.
\end{abstract}

Keywords: stream pollution, groundwater contamination, water quality monitoring, physicochemical parameters, microbiological analysis

\section{Introduction}

The main component in any form of life on the planet earth is water and the absence of water would imply impossibility of the existence of life. Water on the earth surface is approximately $97 \%$ and this is located in the ocean. However, only $3 \%$ of this water on earth was held as freshwater sources and out of this, groundwater constitutes about $30.1 \%$ of the total fresh water resources (Eugene et al., 2014). In many parts of the world, groundwater is a major source for domestic and agricultural use in form of irrigation. It is generally considered the least polluted water resources compared to other surface water sources such as lakes, streams, rivers, springs and so on. However, recent studies have opined that ground water is not totally free from pollution, but may be heavily polluted though the process may be slow but its effects are usually very dreadful (Boufekane and Saighi, 2013).

According to a Salaam-Blyther (2012) report for United States Members and Committees of Congress, World Health Organization (WHO) and the United Nations Children's Fund (UNICEF) recount that roughly 780 million people around the world lack access to clean drinking water and an estimated 2.5 billion people which is roughly $40 \%$ of the world's population are without access to safe sanitation facilities. Rapid industrialization in developing 
countries though has enormously contributed to economic development, has been reported to lead to economic welfare heavy losses in terms of effects on agricultural activities, human health and ecosystem at large through air and water pollution (Reddy \& Behera, 2006). While the magnitude of the problem is limited and widely spread, the losses inherent are quite substantial due to its direct impact on human health and livelihoods.

The human quest to subdue nature has replaced the ability to integrate with natural realities and beauty. Natural realities and beauty of the environment in the sense of keeping the environment green and safe for inhabitants (man and animals) living in such environment. In order for development to take place, which by implication developing rural communities into urban communities through urbanization, population growth and all other associated developments. According to a United Nations University International Network on Water, Environment and Health (UNU-INWEH) report, population growth is projected to continue at an unsustainable rate in developing countries. This inadvertently will lead to increased urbanization and the intensification of agriculture in many parts of the world, are directly linked to decreasing water quality and availability (Schuster-Wallace, 2008). This has resulted in an imbalance situation, which leads to adverse effects on human behaviour, quality of life as well as on available quantity and quality of water resources (Collin \& Melloul, 2003).

Discharge of wastewater to the sea is an additional disposal option in coastal areas according to Oelofse et al. (2004), this is based on the condition that the marine environment is able to cope with the strength of the wastewater and will remain fit for use by its other user along the stream or water courses downstream session. Equally important is the discharges of wastewater to the water resource in inland areas which have to meet certain standards in order to meet predetermined resource quality objectives set for the receiving water resources without degradation. Unlike the protection of surface water from point and non-point pollution sources which are much easier due to its self-purification from natural wetlands, groundwater has a slow update cycle and a weak self-purification capacity, once it is contaminated, the removal, treatment, rehabilitation of polluted groundwater are very difficult and very expensive which may need a heavy investment, high technology, and a long period of time (You-Hailin et al., 2011). Groundwater vulnerability study is the important work for the rational development, utilization and protection of groundwater resources. According to Sangodoyin and Agbawhe (1992), surface and ground water pollution is a major problem in most developing nations; the source and nature of contamination however vary from one nation to another. In South western Nigeria, environmental problems have been reported to be on the increased in geometric proportion over the last three decades with improper management practices being largely responsible for the gross pollution of the aquatic environment with concomitant increase in water borne diseases especially typhoid, diarrhea and dysentery (Osibanjo \& Adie, 2007).

In vast majority of developing countries majorly in Africa and asia, the cost of sustainable waste management is a major challenge for the waste industry. Even though experiences in one country cannot directly be exported to another according to Ragossnig and Vujic (2015), it is of paramount importance to learn about reasons for failures in order to avoid previous mistakes and spending more money than necessary. However, the biggest challenge in developing countries is political instability and if not given adequate attention, transition period from mere dumping as is practiced in the study location to a state-of-the-art waste management system will not just take 30 years as in the Middle European countries, but could take forever. Hence, there is need to objectively assess groundwater pollution level at the location of study so as to be able to proffer site specific solutions to the problem. Therefore the objective of this study is to determine the pollution impact of Gege stream flow on selected riparian wells along its course.

\section{Materials and Methods}

STUDY AREA: Ibadan is located on geographic grid reference longitude $3^{\circ} 5 \mathrm{E}$, latitude $7^{\circ} 20 \mathrm{~N}$ and at an average height of $220 \mathrm{~m}$ above mean sea level; drained by four river basins and surrounded by secondary rainforest as well as a savanna. Spatially, it sprawls over a radius of $12-15 \mathrm{~km}$ and experiences mainly tropical climate with an estimated annual rainfall of about $1250 \mathrm{~mm}$.

Households are very close to the stream which serves as a means of domestic waste water, solid wastes and abattoir effluents disposal in the study area along Gege stream water body (Figure 1). Groundwater samples were collected from upstream (w1), mid-stream (w2) and down-stream (w3 and w4) and the sampling points are approximately $60 \mathrm{~m}$ apart. The samples were collected from 4 tube wells (w1, w2, w3, and w4,) located at both sides near Gege stream at $20 \mathrm{~m}(\mathrm{w} 1), 30 \mathrm{~m}(\mathrm{w} 2), 39 \mathrm{~m}(\mathrm{w} 3)$, and $20 \mathrm{~m}$ (w4), making a total of 8 sampling wells respectively (Figure 2). Sampling spanned 2011 and 2012 from March to July in respective years and this were depicted as A, B, C, D, and $\mathrm{E}$ in 2011 and F, G, H, I, and J in 2012 respectively with a 2-week sampling interval from 8 out of the 13 wells located at the location of study. The sampling period falls within the dry and rainy seasons in Southwest Nigeria. 
Parameters analyzed were $\mathrm{Pb}, \mathrm{cu}, \mathrm{mg}^{++} \mathrm{Al}, \mathrm{Fe}, \mathrm{DO}, \mathrm{BOD}_{5}, \mathrm{COD}$, TS, TDS, $\mathrm{EC}, \mathrm{Cl}$, and microbial characteristic's using standard method for wastewater examination. (APHA, 1998).

\subsection{Physico-Chemical Determination of Pollutants in Waste-Water}

Collected samples $\mathrm{pH}$ was determined using Hach Pocket Pro $\mathrm{P}^{\mathrm{H}}$ Tester (model No. 9531000), while temperature was determined using portable calibrated mercury thermometer (Jenway 3015 model). Samples for heavy metals (Lead, Cadmium, Manganese, Iron, Zinc) were collected separately and acidified with concentrated nitric acid to keep the metals in solution and to minimize their absorption to the walls of the sample bottle. Atomic Absorption spectrophotometer was used to determine the level of heavy metals in the samples by the following method. Samples were concentrated by evaporating $100 \mathrm{ml}$ of sample to about $20 \mathrm{ml}$ and thereafter aspirated through the nebulizer into the air-acetylene flame where the atomization took place. Using a source lamp for each element, the amount of energy absorbed in the flame was proportional to the concentration of element in the sample over a limited concentration range.

\subsection{Microbiological Analysis of Waste-Water}

Moist Heat Method was used to culture media in flasks, bottles and media used for biochemical analysis. Moist heat sterilization was accomplished by using an autoclave at $121{ }^{\circ} \mathrm{C}$ for 15 minutes. Absorbent cotton was soaked in alcohol or methylated spirit and it was used to wipe the work benches and surface before each experiment to ensure a reasonably aseptic working condition. Open flames were used as a means of preventing contamination. This was done by lighting Sprit-lamp in order to minimize and/or eliminate contamination. Non-absorbent cotton wool which had been wrapped in aluminium plus oil was also used to cover the mouth of the various conical flasks and tubes used before autoclaving. This was done to prevent the media from being contaminated during and after sterilization.

All glass bottle was washed with distilled water and sterilized. Two drops of $1.8 \%$ sodiumthiosulphate was added to the bottles before sterilization with chlorinated water. Media was prepared by weighing $28 \mathrm{~kg}$ of nutrient agar. It was poured into a sterile conical flask and one liter of distilled water was added to it, stirred and covered with non-absorbent cotton wool and foil and it was autoclaved at $121{ }^{\circ} \mathrm{C}$. Cool to room temperature to avoid decomposition of sugars by prolonged exposure to heat.

Water samples were serially diluted using the sterilized pipette to take $3 \mathrm{ml}$ of distilled water into a sterile test tube and $1 \mathrm{ml}$ of sample was added to the $3 \mathrm{ml}$ of distilled water, from this dilution $1 \mathrm{ml}$ was taken into another sterile test tube containing $3 \mathrm{ml}$ of water. This was done for five times to reduce water samples microbial load. One ml of each of the serially diluted water sampoles were aseptically transferred into sterile petri-dishes, freshly prepared sterile nutrient agar was aseptically pored on to the petri-dishes containing water samples. This was agitated for 30 seconds to allow even distribution of possible microbial load. It was allowed to solidify before transferring into incubator $37^{\circ} \mathrm{C}$ for 24 hours.

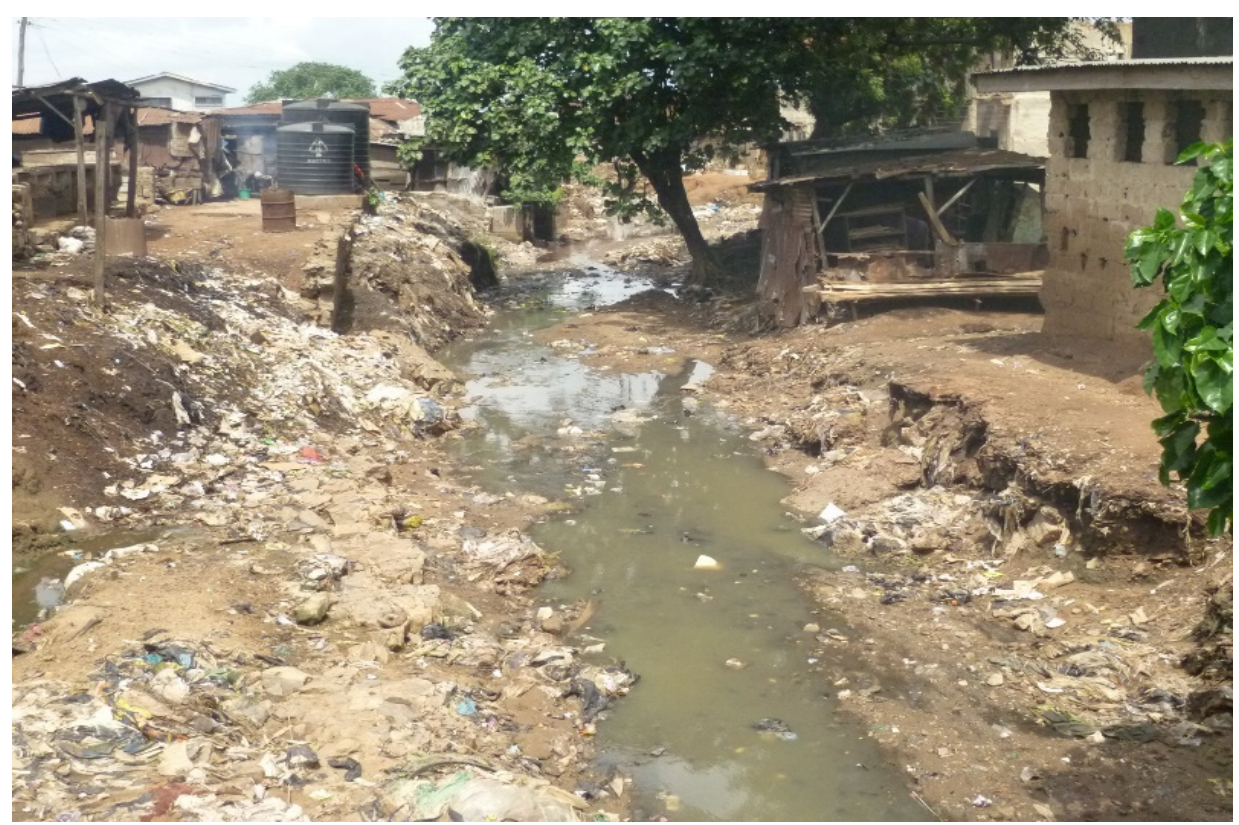

Figure 1. Polluted Gege stream with residential houses less than $3 \mathrm{~m}$ to the stream 


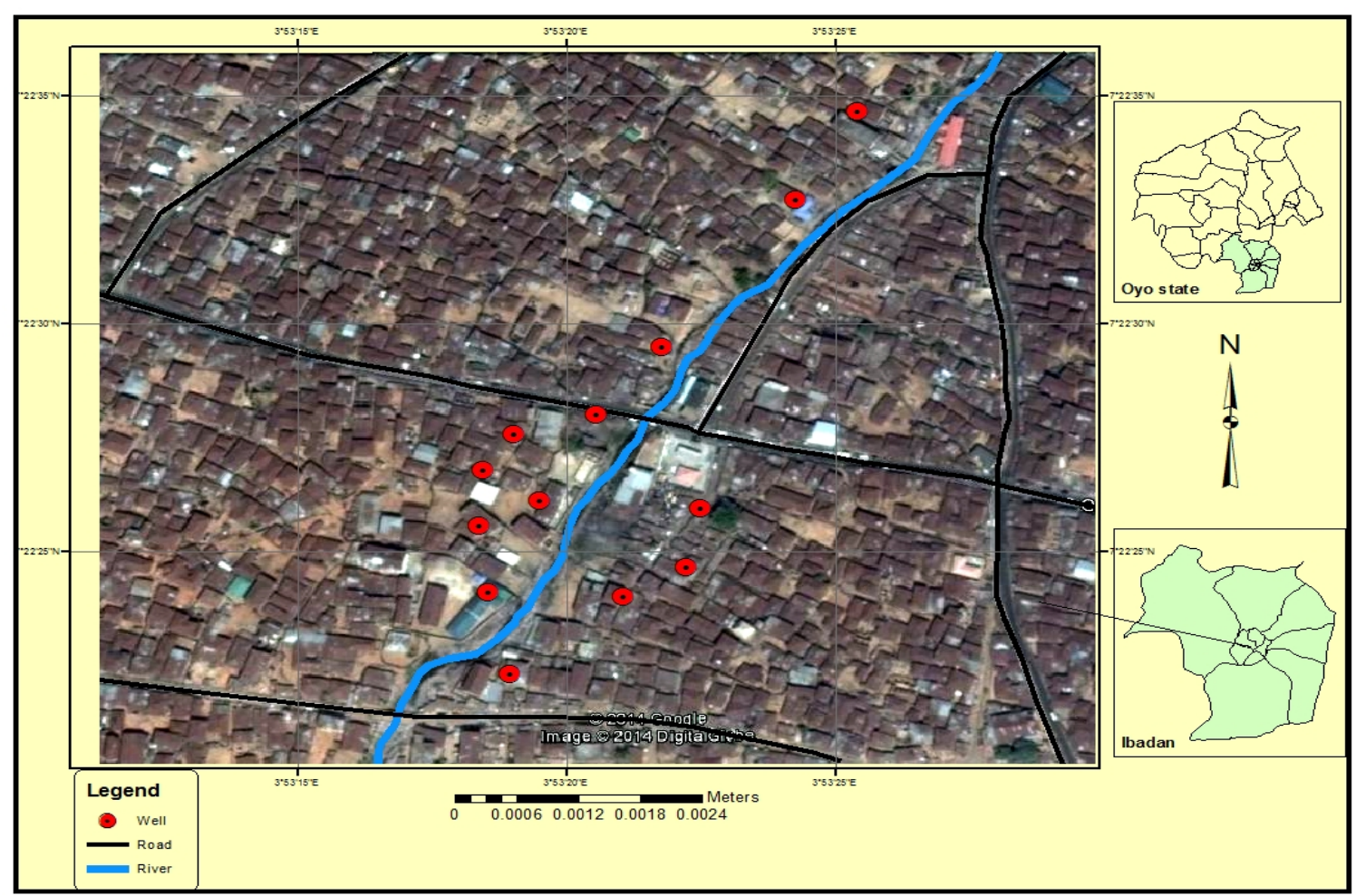

Figure 2. Sampling well locations along Gege stream

\section{Results and Discussion}

Physico-chemical and microbiological analysis of water samples of Gege stream are shown in Table 1; except for temperature which does not show a specific variation pattern. The values of some parameters recorded were found to be higher compared to WHO standard for fresh water quality use in almost all the samples. All the following compounds $\left(\mathrm{Pb}^{2+}, \mathrm{Cu}^{2+}, \mathrm{Mg}^{2+}, \mathrm{Fe}^{2+}\right.$ all in mg/l) were within acceptable limits according to WHO (2008) water quality standards.

In the eight observation wells, Chloride detected ranged between 11-22 mg/l and excessive chloride concentrations increase rates of corrosion of metals in water distribution system, depending on the alkalinity of the water. No health-based guideline value is proposed for chloride, iron, $\mathrm{pH}$ and sulphate in drinking-water. However, chloride concentrations in excess of about $250 \mathrm{mg} / \mathrm{l}$ can give rise to detectable taste in water (WHO, 2008). In all the wells sampled, the $\mathrm{pH}$ ranged 7.0-7.9 indicating that the water falls on acceptable guideline value of $\mathrm{pH}$ range based on aesthetic considerations (WHO, 2007). However, no health-based guideline value was proposed for $\mathrm{pH}$ in the 1993 WHO Guidelines as it has no direct impact on consumers. Howbeit, it is one of the most important operational water quality parameters, with the optimum $\mathrm{pH}$ required often being in the range 6.5-9.5 (WHO, 2008).

Similarly, no health-based guideline is proposed for sulphate by W.H.O., however because of gastrointestinal effects resulting from ingestion of drinking-water containing high sulphate levels, it is recommended that drinking water that contain sulfate concentrations in excess of $500 \mathrm{mg} / \mathrm{l}$ should be avoided. Apart of the gastrointestinal effects, the presence of sulfate in drinking-water may also cause noticeable taste and may contribute to the corrosion of water distribution systems (WHO, 2008).

Total Dissolve Solids (TDS) results in all the wells ranged between 330-1805 mg/l and this is known to comprise principally of inorganic salts such as calcium, magnesium, potassium, sodium, bicarbonates, chlorides, sulfates and small amounts of organic matter. No health-based guideline value is proposed according to World Health Organisation; however the presence of high levels of TDS in drinking-water above $1000 \mathrm{mg} / \mathrm{l}$ may be objectionable to consumers. Hence, all residents residing close to the sampling point $\mathrm{E}$ may be experiencing some undesirable water quality taste due to the higher concentrations of TDS found within these wells. This high level of TDS values may be attributed to the dumping of refuse and other solid wastes along the course of the river as seen in Figure 1. 
Table 1. Physico-Chemical Analysis of Gege Stream Water Samples

\begin{tabular}{|c|c|c|c|c|c|c|c|c|c|c|c|}
\hline Parameters & Sampling points & $\mathbf{A}$ & B & $\mathrm{C}$ & D & $\mathbf{E}$ & $\mathbf{F}$ & G & H & I & $\mathbf{J}$ \\
\hline \multirow{4}{*}{$\mathrm{Pb}^{2+}(\mathrm{mg} / / \mathrm{L})$} & w1 & 0.01 & 0.01 & 0.01 & 0.01 & 0.01 & 0.01 & 0.01 & 0.01 & 0.01 & 0.01 \\
\hline & w2 & 0.01 & 0.01 & 0.01 & 0.01 & 0.01 & 0.01 & 0.01 & 0.01 & 0.01 & 0.01 \\
\hline & w3 & 0 & 0 & 0 & 0 & 0 & 0 & 0 & 0 & 0 & 0 \\
\hline & w4 & 0 & 0 & 0 & 0 & 0 & 0 & 0 & 0 & 0 & 0 \\
\hline \multirow{4}{*}{$\mathrm{Cu}^{2+}(\mathrm{mg} / / \mathrm{L})$} & w1 & 0.05 & 0.05 & 0.04 & 0.04 & 0.035 & 0.03 & 0.035 & 0.035 & 0.03 & 0.34 \\
\hline & w2 & 0.05 & 0.05 & 0.05 & 0.05 & 0.1 & 0.04 & 0.03 & 0.03 & 0.01 & 0.01 \\
\hline & w3 & 0.05 & 0.2 & 0.2 & 0.2 & 0.06 & 0.03 & 0.025 & 0.2 & 0.2 & 0.2 \\
\hline & w4 & 0.05 & 0.03 & 0.02 & 0.02 & 0.03 & 0.04 & 0.02 & 0.015 & 0.01 & 0.04 \\
\hline \multirow{4}{*}{$\mathrm{Mg}^{2+}(\mathrm{mg} / / \mathrm{L})$} & w1 & 2.35 & 2.5 & 2.5 & 2.5 & 2.2 & 2.3 & 2 & 2.2 & 2.4 & 2.4 \\
\hline & w2 & 3 & 3.5 & 3.5 & 3.5 & 3.5 & 3.5 & 3 & 3 & 3.5 & 3.2 \\
\hline & w3 & 2 & 2.5 & 2.5 & 2.5 & 2.25 & 2.35 & 2.2 & 2 & 2 & 3.2 \\
\hline & w4 & 2.1 & 2.5 & 2.5 & 2.5 & 1.45 & 2.7 & 2.5 & 2.5 & 2.7 & 2.6 \\
\hline \multirow{4}{*}{$\mathrm{Fe}^{2+}(\mathrm{mg} / / \mathrm{L})$} & w1 & 0.4 & 0.3 & 0.3 & 0.3 & 0.25 & 0.3 & 0.3 & 0.4 & 0.3 & 0.2 \\
\hline & w2 & 0.2 & 0.2 & 0.2 & 0.2 & 0.2 & 0.2 & 0.3 & 0.4 & 0.4 & 0.4 \\
\hline & w3 & 0.2 & 0.2 & 0.2 & 0.2 & 0.1 & 0.1 & 0.1 & 0.3 & 0.3 & 0.1 \\
\hline & w4 & 0.1 & 0.1 & 0.1 & 0.1 & 0.1 & 0.1 & 0.2 & 0.5 & 0.2 & 0.3 \\
\hline \multirow{4}{*}{$\mathrm{pH}(\mathrm{mg} / / \mathrm{L})$} & w1 & 7.85 & 7.8 & 7.8 & 7.7 & 7.55 & 7.5 & 7.4 & 7.3 & 7.15 & 7.19 \\
\hline & w2 & 7.9 & 7.85 & 7.85 & 7.75 & 7.6 & 7.45 & 7.4 & 7.5 & 7.45 & 7.46 \\
\hline & w3 & 7.65 & 7.55 & 7.55 & 7.5 & 7.15 & 7.1 & 7.2 & 7.2 & 7.3 & 7 \\
\hline & w4 & 7 & 7 & 7 & 7.2 & 14.7 & 7.2 & 7.1 & 7.2 & 7.3 & 7.6 \\
\hline \multirow{4}{*}{$\mathrm{DO}(\mathrm{mg} / / \mathrm{L})$} & w1 & 3.7 & 4.25 & 4.25 & 4.25 & 4.2 & 4.2 & 4.5 & 4.45 & 4.5 & 4.13 \\
\hline & w2 & 3.55 & 4.55 & 4.55 & 4.55 & 4.3 & 4.3 & 4.2 & 4.05 & 4.1 & 4 \\
\hline & w3 & 4.5 & 4.5 & 4.5 & 4.5 & 4.5 & 4.65 & 4.8 & 4.8 & 4.7 & 4.16 \\
\hline & w4 & 5.5 & 5 & 5 & 4 & 4.3 & 4.2 & 4.2 & 4.2 & 4.3 & 5.1 \\
\hline \multirow{4}{*}{$\mathrm{BOD}_{5}(\mathrm{mg} / / \mathrm{L})$} & w1 & 9.55 & 9 & 9 & 9 & 7.5 & 7 & 6 & 6 & 6.25 & 6.16 \\
\hline & w2 & 6 & 6.5 & 6.5 & 6.5 & 5 & 4 & 4 & 4.55 & 4.6 & 4.1 \\
\hline & w3 & 5 & 4 & 4.5 & 4 & 2 & 2 & 1.5 & 1.5 & 1.2 & 1.59 \\
\hline & w4 & 4.25 & 3 & 3 & 3 & 3 & 3 & 2 & 2 & 2.3 & 3.2 \\
\hline \multirow{4}{*}{$\operatorname{COD}(\mathrm{mg} / / \mathrm{L})$} & w1 & 18.25 & 15.75 & 15.75 & 15.75 & 13.5 & 11.5 & 10.5 & 10.5 & 11 & 11.1 \\
\hline & w2 & 10.5 & 11 & 11 & 11 & 8.5 & 7.5 & 6.5 & 7 & 7.5 & 6.11 \\
\hline & w3 & 8.75 & 5 & 5 & 5 & 3.5 & 3.25 & 3 & 2.65 & 2 & 2.12 \\
\hline & w4 & 6.75 & 4.75 & 4.75 & 4.75 & 4.5 & 4 & 3.5 & 3.5 & 3.75 & 3.13 \\
\hline \multirow{4}{*}{ TDS (mg//L) } & w1 & 570 & 570 & 530 & 490 & 1518.5 & 475 & 460 & 440 & 450 & 439 \\
\hline & w2 & 545 & 520 & 520 & 480 & 1805 & 470 & 450 & 420 & 425 & 411 \\
\hline & w3 & 525 & 425 & 425 & 380 & 1415 & 355 & 345 & 345 & 340 & 346 \\
\hline & w4 & 430 & 330 & 330 & 365 & 1386 & 352.5 & 350 & 360 & 365 & 371 \\
\hline \multirow{4}{*}{$\mathrm{TS}(\mathrm{mg} / / \mathrm{L})$} & w1 & 165.9 & 1614 & 1614 & 1543.5 & 1543.5 & 1518.5 & 1540 & 1585 & 1565 & 1413.5 \\
\hline & w2 & 2048.5 & 2110 & 2110 & 1839.5 & 3679 & 1805 & 1695 & 1740 & 1635 & 3776 \\
\hline & w3 & 1580 & 1480 & 1480 & 2865 & 2864 & 1415 & 1405 & 1380 & 1380 & 1490 \\
\hline & w4 & 14075 & 1347 & 1347 & 1375.5 & 1375.5 & 1386 & 1355 & 2830 & 2870 & 3827 \\
\hline \multirow{4}{*}{$\operatorname{EC}(\mu)$} & w1 & & 1545 & 1545 & 750 & 705 & 701 & 705 & 712.5 & 712.5 & 712.7 \\
\hline & w2 & 2017.5 & 2005 & 2005 & 8075 & 812.5 & 726.5 & 725 & 740 & 720 & 735 \\
\hline & w3 & 1957.5 & 1057.5 & 2117 & 1022.5 & 1004 & 978 & 985 & 855 & 840 & 825 \\
\hline & w4 & 980 & 577.5 & 1155 & 550 & 565 & 557.5 & 555 & 570 & 565 & 562 \\
\hline \multirow{4}{*}{$\mathrm{Cl}^{-}(\mathrm{mg} / / \mathrm{L})$} & w1 & 18.25 & 16 & 16 & 15.5 & 12 & 11 & 12 & 12.5 & 12 & 12 \\
\hline & w2 & 15.5 & 14 & 14 & 12 & 12 & 12.5 & 11.5 & 11 & 11.5 & 12 \\
\hline & w3 & 12.25 & 15 & 15 & 13.25 & 13.5 & 14 & 13.5 & 12.25 & 12.5 & 12.13 \\
\hline & w4 & 22 & 21 & 21 & 18 & 16.75 & 16 & 15 & 13 & 12 & 12.56 \\
\hline \multirow{4}{*}{$\mathrm{NO}^{3}(\mathrm{mg} / / \mathrm{L})$} & w1 & 3 & 3.25 & 3.4 & 2.2 & 2 & 0.3 & 0.45 & 0.4 & 0.35 & 0.37 \\
\hline & w2 & 3.5 & 3.5 & 3.5 & 2.5 & 2.5 & 0.5 & 0.3 & 0.4 & 0.4 & 0.4 \\
\hline & w3 & 1.7 & 1.5 & 1.5 & 1 & 1 & 0.3 & 0.3 & 0.3 & 0.3 & 0.3 \\
\hline & w4 & 1.2 & 1 & 1 & 1 & 1 & 0.4 & 0.5 & 0.5 & 0.4 & 0.4 \\
\hline
\end{tabular}

Total coliform counts and faecal coli form counts for all samples are shown in Table 2. Prevalent bacteria present in the samples include Enterobacter sp., Proteus sp., Pseudomonas sp. and Klebsiella sp, Aromonas sp. and Escherichia Coli was not present in the entire well water sample collected (Table 3), while characteristics of bacterial isolated were showed in table 4 . All water samples showed the presence of faecal contaminants which was higher than WHO water standard. Faecal coliforms and total coliform count confirms, were observed in the entire sample collected, this might be attributed to direct discharge from different tributaries from house hold wastewater and discharge of abattoir waste both solid and liquid into the water body and surface run-off. The presence of E. coli and others is an indication of human faecal contamination. Nitrate in the samples are not to high compared to WHO standard but its presence proves harmful especially to infants causing cyanosis or blue baby syndrome infant if ingested. 
Table 2. Coliforms Present in Water Sample

\begin{tabular}{|c|c|c|c|c|c|c|c|c|c|c|c|}
\hline Counts $/ \mathrm{ml}$ & $\begin{array}{c}\text { Sampling } \\
\text { Points }\end{array}$ & $\mathbf{A}$ & B & C & D & $\mathbf{E}$ & $\mathbf{F}$ & G & $\mathbf{H}$ & I & $\mathbf{J}$ \\
\hline \multirow{4}{*}{$\begin{array}{c}\text { Total coliform } \\
\text { count }(\mathrm{cfu} / \mathbf{1 0 0 m \mathrm { m } )}\end{array}$} & w1 & $1.2 \times 10^{4}$ & $2.5 \times 10^{4}$ & $2.2 \times 10^{4}$ & $2.2 \times 10^{4}$ & $2.7 \times 10^{4}$ & $3.2 \times 10^{4}$ & $3.0 \times 10^{4}$ & $3.6 \times 10^{4}$ & $3.5 \times 10^{4}$ & $3.9 \times 10^{4}$ \\
\hline & w2 & $2.2 \times 10^{4}$ & $2.8 \times 10^{4}$ & $2.8 \times 10^{4}$ & $2.9 \times 10^{4}$ & $3.2 \times 10^{4}$ & $3.0 \times 10^{4}$ & $3.5 \times 10^{4}$ & $4.0 \times 10^{4}$ & $3.8 \times 10^{4}$ & $3.6 \times 10^{4}$ \\
\hline & w3 & $4.5 \times 10^{3}$ & $4.2 \times 10^{3}$ & $4.2 \times 10^{3}$ & $6.0 \times 10^{3}$ & $6.8 \times 10^{3}$ & $7.2 \times 10^{3}$ & $7.0 \times 10^{3}$ & $8.3 \times 10^{3}$ & $8.2 \times 10^{3}$ & $9.1 \times 10^{3}$ \\
\hline & w4 & $3.27 \times 10^{3}$ & $3.5 \times 10^{3}$ & $3.5 \times 10^{3}$ & $7.0 \times 10^{3}$ & $8.5 \times 10^{3}$ & $8.0 \times 10^{3}$ & $6.5 \times 10^{3}$ & $7.2 \times 10^{3}$ & $7.0 \times 10^{3}$ & $4.2 \times 10^{3}$ \\
\hline \multirow{4}{*}{$\begin{array}{l}\text { Faecal coliform } \\
\text { count }(\mathrm{cfu} / \mathbf{1 0 0 m \mathrm { m } )}\end{array}$} & w1 & $1.2 \times 10^{2}$ & $1.0 \times 10^{2}$ & $1.0 \times 10^{2}$ & $1.6 \times 10^{2}$ & $1.8 \times 10^{2}$ & $1.6 \times 10^{2}$ & $1.8 \times 10^{2}$ & $2.2 \times 10^{2}$ & $2.4 \times 10^{2}$ & $2.5 \times 10^{2}$ \\
\hline & w2 & $1.5 \times 10^{5}$ & $1.5 \times 10^{5}$ & $1.5 \times 10^{5}$ & $2.8 \times 10^{5}$ & $3.3 \times 10^{2}$ & $2.8 \times 10^{5}$ & $2.6 \times 10^{5}$ & $2.8 \times 10^{5}$ & $2.6 \times 10$ & $3.5 \times 10^{2}$ \\
\hline & w3 & Nil & Nil & Nil & Nil & Nil & Nil & Nil & Nil & Nil & Nil \\
\hline & w4 & Nil & Nil & Nil & $2.2 \times 10^{2}$ & $2.0 \times 10^{2}$ & $1.7 \times 10^{2}$ & $2.0 \times 10^{2}$ & $2.5 \times 10^{2}$ & $2.4 \times 10^{2}$ & $2.4 \times 10^{2}$ \\
\hline \multirow{4}{*}{$\begin{array}{l}\text { Streptoccus } \\
\text { faecalis } \\
(\mathbf{c f u} / 100 \mathrm{ml})\end{array}$} & w1 & Nil & Nil & Nil & Nil & Nil & Nil & Nil & Nil & Nil & Nil \\
\hline & w2 & Nil & Nil & Nil & Nil & Nil & Nil & Nil & Nil & Nil & Nil \\
\hline & w3 & Nil & Nil & Nil & Nil & Nil & Nil & Nil & Nil & Nil & Nil \\
\hline & w4 & Nil & Nil & Nil & Nil & Nil & Nil & Nil & Nil & Nil & Nil \\
\hline
\end{tabular}

A - J Sampling interval (Every two weeks from March to July in 2011 and 2012)

w1 Mean sample value from well 1 at both sides

w2 Mean sample value from well 2 at both sides

w3 Mean sample value from well 3 at both sides

w4 Mean sample value from well 4 at both sides

Table 3. Prevalence Bacteria Isolates in Water Samples

\begin{tabular}{|c|c|c|c|c|c|c|c|}
\hline & & Klebsiella sp. & Enterobacter sp. & Proteus sp. & Aromonas sp. & Escherichia Coli & Pseudomonas sp. \\
\hline \multirow{4}{*}{$\mathbf{A}$} & w1 & - & + & - & - & + & + \\
\hline & w2 & - & - & + & - & + & + \\
\hline & w3 & - & - & + & + & - & + \\
\hline & w4 & - & + & + & + & - & + \\
\hline \multirow{4}{*}{ B } & w1 & - & - & - & - & + & + \\
\hline & w2 & - & - & + & - & + & + \\
\hline & w3 & - & - & + & + & - & + \\
\hline & w4 & - & + & + & - & - & + \\
\hline \multirow{4}{*}{$\mathrm{C}$} & w1 & - & - & - & - & + & + \\
\hline & w2 & - & - & + & - & + & + \\
\hline & w3 & - & - & + & + & - & + \\
\hline & w4 & - & + & + & + & - & + \\
\hline \multirow{4}{*}{ D } & w1 & - & - & - & - & + & + \\
\hline & w2 & - & - & + & - & + & + \\
\hline & w3 & - & - & + & + & - & + \\
\hline & w4 & - & - & + & + & + & + \\
\hline \multirow{4}{*}{$\mathbf{E}$} & w1 & - & - & - & + & + & + \\
\hline & w2 & - & - & + & - & + & + \\
\hline & w3 & - & + & + & + & - & + \\
\hline & w4 & - & + & + & + & + & + \\
\hline \multirow{4}{*}{$\mathbf{F}$} & w1 & - & - & - & - & + & + \\
\hline & w2 & - & - & + & - & + & + \\
\hline & w3 & - & - & + & - & - & + \\
\hline & w4 & - & + & + & + & + & + \\
\hline
\end{tabular}




\begin{tabular}{|c|c|c|c|c|c|c|c|}
\hline & w1 & - & - & + & - & + & - \\
\hline \multirow{4}{*}{$\mathbf{G}$} & w2 & - & - & + & - & + & + \\
\hline & w3 & - & - & + & + & - & + \\
\hline & w4 & - & + & + & - & + & + \\
\hline & w1 & - & - & - & + & + & + \\
\hline \multirow{4}{*}{ H } & w2 & - & - & + & + & + & - \\
\hline & w3 & - & - & + & - & - & - \\
\hline & w4 & - & + & + & - & + & + \\
\hline & w1 & - & - & + & - & + & + \\
\hline \multirow{4}{*}{ I } & w2 & - & - & + & - & + & + \\
\hline & w3 & - & - & + & + & - & + \\
\hline & w4 & - & + & + & + & + & + \\
\hline & w1 & - & + & - & - & + & + \\
\hline \multirow{3}{*}{$\mathbf{J}$} & w2 & - & + & + & - & + & + \\
\hline & w3 & - & - & + & + & - & + \\
\hline & w4 & - & - & + & + & + & + \\
\hline
\end{tabular}

KEY - Bacteria not present; + Bacteria present.

\section{Conclusion and Recommendations}

It can be concluded that wells dug along Gege stream and its environs contains bacteria which are harmful to the resident population within the vicinity of the polluted stream. Hence, all the wells sampled showed one degree of pollution or the other from physico-chemical and/or bacteriological parameters. It is hereby recommended that wells within $40 \mathrm{~m}$ radius from the Gege stream should be discontinued for use as domestic water supply and even agricultural water usage in peasant backyard irrigated agriculture of aesthetic plants and vegetables. This finding was in accordance with the recommendations of Adekunle et al. (2007) which stated that wells located within 50m from pollution sources should be abandoned and future wells should be constructed beyond $250 \mathrm{~m}$ from pollution sources.

Furthermore, urgent and swift action should be taken by government and other stakeholders in urban slums management in Ibadan, southwest Nigeria by making sure proper and approved building master plans are adhered to in urban slums and ensuring minimum distance from river or stream banks are observed. Public and private partnerships through dialogues and if possible, sanctions should also be put in place in case of defaulters. Also, waste management through cleaner production and adoption of cleaner technologies will go a long way in curbing the environmental degradation resulting to health risks posed by these stream pollution leading to groundwater pollution that has been reported to be difficult to remediate once polluted. Also, there should be public awareness about the need to have a proper good personal hygiene for a healthy life and in addition to this, efficient solid waste management should be adopted to safeguard public health from water borne diseases, especially riparian residents.

\section{References}

Adekunle, I. M., Adetunji, M. T., Gbadebo, A. M., \& Banjoko, O. B. (2007) Assessment of Groundwater Quality in a Typical Settlement in Southwest Nigeria. International Journal of Environmental Research and Public Health, 4(4), 07-318.

APHA. (1998) Standard Methods of Examination of Water and Wastewater (20th ed.). American Public Health Association (APHA), Washington D.C

Boufekane, A., \& Saighi, O. (2013) Assessment of Groundwater Pollution by Nitrates using Intrinsic Vulnerability Methods: A Case Study of the Nil Valley Groundwater (Jijel, North-East Algeria). African Journal of Environmental Science and Technology, 7(10), 949-960.

Collin, M. L., \& Melloul, A. J. (2003). Assessing Groundwater Vulnerability to Pollution to Promote Sustainable Urban and Rural Development Journal of Cleaner Production, 11, 727-736.

Eugene, L. R., Shylla, R., \& Singh, O. P. (2014). Assessment of Ground Water Quality from Dug Wells in West Jaintia Hills District, Meghalaya, India. International Journal of Environmental Sciences, 5(3), 544-552. 
Hailin, Y., Ligang, X., Chang, Y., \& Jiaxing, X. (2011). Evaluation of groundwater vulnerability with improved DRASTIC method. Procedia Environ Sci, 10, 2690-2695.

Oelofse, S. H. H., Viljoen, P., Taljaard, S., \& Botes, W. A. M. (2004). Discharge of Water Containing Waste Emanating from Land to the Marine Environment: A Water Quality Management Perspective Water SA, 30(5, Special Edition). Retrieved from http://www.wrc.org.za

Osibanjo, O., \& Adie, G. U. (2007). Impact of Effluent from Bodija Abattoir on the Physico-chemical Parameters of Oshunkaye Stream in Ibadan City, Nigeria. African Journal of Biotechnology, 6(15), 1806-1811.

Ragossnig, A. M., \& Vujic, G. (2015). Challenges in Technology Transfer from Developed to Developing Countries Waste Management and Research, 33(2), 93-95. Retrieved February 20, 2015, from wmr.sagepub.com

Reddy, V. R., \& Behera, B. (2006). Analysis Impact of Water Pollution on Rural Communities: An Economic Analysis. Ecological Economics, 58, 520-537. http://dx.doi.org/10.1016/j.ecolecon.2005.07.025

Salaam-Blyther, T. (2012, September). Global access to clean drinking water and sanitation: US and international programs. In Congressional Research Service Report for Congress (p. 36).

Sangodoyin, A. Y., \& Agbawhe, O. M. (1992). Environmental study on surface and ground water pollutants from abattoir effluent Bio-resource Technology, 41, 193-200.

Schuster-Wallace, C. J., Grover, V. I., Adeel, Z., Confalonieri, U., \& Elliot, S. (2008). Safe water as the key to global health. United Nations University International Network on Water. Environment and Health (UNUINWEH), Hamilton, ON. Retrieved February 14th, 2015, from www.inweh.unu.edu

WHO. (2007). $\mathrm{pH}$ in drinking-water. Background document for preparation of WHO Guidelines for drinking-water quality. Geneva, World Health Organization (WHO/SDE/WSH/07.01/1).

WHO. (2008). Guidelines for Drinking Water Quality (3rd ed.). World Health Organization Press, 20 Avenue Appia, 1211 Geneva 27, Switzerland.

\section{Copyrights}

Copyright for this article is retained by the author(s), with first publication rights granted to the journal.

This is an open-access article distributed under the terms and conditions of the Creative Commons Attribution license (http://creativecommons.org/licenses/by/3.0/). 